\title{
Presentación
}

\section{PASADO FUTURO}

Los diversos textos que configuran el presente dossier, a pesar de su heterogeneidad temática, y la diversidad de sus métodos y enfoques, parecen provenir de una zona común de los estudios literarios y culturales actuales. Se trata de la insistencia en cómo un retorno a prácticas de escritura o expresión artística del pasado, más o menos reciente, no sólo permite configurar los rompecabezas del presente, sino anticipar los movimientos y lugares de futuros posibles.

A este respecto, en la mayoría de los casos, dicho retorno a los espacios del ayer se da en momentos de tensión política y humana cuyo alcance no ha sido prestigiado por las narrativas fuertes; o no del todo. Es decir, en pequeños pliegues en las historias nacionales, y en la continental -a veces-, que no han quedado registrados por las historiografías y sus estrategias para homogeneizar y ocultar procesos de verdadera transformación, en un lado, o de honda violencia, y oscuridad, en el otro.

En términos simples, los estudios aquí reunidos insisten en la fuerza que los enfoques actuales de la ciencias humanas poseen a la hora de recuperar pequeños deslices, o desajustes, para bien o para mal, que muchas veces sólo pueden ser registrados por los performances de la escritura, la representación o los juegos -y desdoblamientos - entre los consabidos aparatos de la experiencia humana: la historia, la literatura y el arte en sí, que a su vez los discursos de lo político, lo social, lo ideológico... siempre acechan y atraviesan.

Así, se pasa por el tratamiento de la violencia política en la figura del infans, en un relato de Osvaldo Lamborghini, como estrategia estética para empoderar al lenguaje (Sättele); por una negación del tiempo mexicano, a través de los juegos entre realidad y ficción, en una reciente novela de Pedro Ángel Palou (Pérez); por el dinamismo y fuerza de lo mítico nahua a la hora de desentrañar el nacimiento de la clase lumpen proletaria mexicana, en José Trigo (Bañuelos); por los juegos políticos de la llamada narcocultura, desde lo literario, a la hora de situarse en la conflictiva posmodernidad (Ritondale); por la adaptación y adecuación de los subgéneros literarios, como estrategia desértica y fronteriza, en las novelas de Gabriel Trujillo Muñoz (Pardo y Tapia); por el poder de la narrativa a la hora de revelar espacios fugados a las instituciones, tomando como ejemplo Salsa y control de José Roberto Duque (Ascanio); por los mecanismos de las crónicas y la figura de La Loca, de Lemebel, a la hora de superar los confines de lo marginal (Franken); y por, finalmente, los conflictos de una (im)posible "cultura ecuatoriana" (Guzmán y Vargas).

Completan este volumen dos textos en la sección miscelánea, que aun manteniendo muchos de las líneas de fuerza aquí descritas, establecen 
diálogos propios, y acaso específicos, sea con la dinámica poética de Pezoa Véliz (Diamantino), o la veracidad de la literatura a la hora de percibir los cambios del mundo, desde un enfoque microsocial de los símbolos literarios, siguiendo a Erving Goffman (García-Peña).

Mauricio Zabalgoitia Herrera (coord.) 